ELORE (ISSN 1456-3010), vol. 20 - 2/2013.

Julkaisija: Suomen Kansantietouden Tutkijain Seura ry.

[http://www.elore.fi/arkisto/2_13/hammarstrom.pdf]

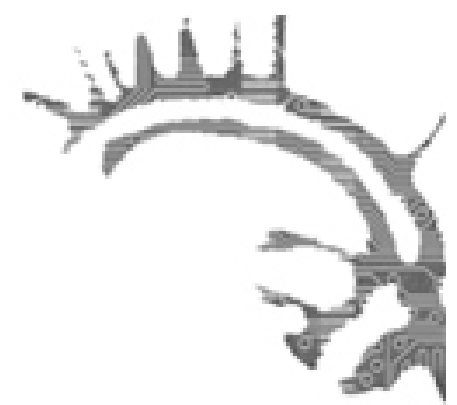

KirJa-ARViO

\title{
SUOMALAISEN MONIKULTTUURISUUDEN MAHDOLLISUUDET
}

\author{
$\underline{\text { Kukka Hammarström }}$
}

MARTIKAINEN, TUOMAS \& SAUKKONEN, PASI \& SÄÄVÄL̈̈, MINNA (toim.) 2013: Muuttajat. Kansainvälinen muuttoliike ja suomalainen yhteiskunta. Helsinki: Gaudeamus. 376 s.

SAUKKONEN, PASI 2013. Erilaisuuksien Suomi. Vähemmistö- ja kotouttamispolitiikan vaihtoehdot. Helsinki: Gaudeamus. 252 s.

Suomi on muuttumassa yhä monikulttuurisemmaksi. Tämä asettaa uusia haasteita niin maahanmuutto-, vähemmistö- kuin kotouttamispolitiikalle ja muuttaa samalla käsityksiä suomalaisesta monikulttuurisuudesta. Näitä teemoja tarkastellaan kahdessa teoksessa, joihin on koottu laajasti aihepiiriä käsittelevää ajankohtaista tietoa. Muuttajat. Kansainvälinen muuttoliike ja suomalainen ybteiskunta on monialainen yleisesitys muuttoliikkeestä ja sen vaikutuksista suomalaiseen yhteiskuntaan erityisesti 1990- ja 2000-lukujen näkökulmasta. Erilaisuuksien Suomi. Vähemmistö-ja kotouttamispolitiikan vaihtoehdot puolestaan rakentaa kuvaa suomalaisesta vähemmistö- ja kotouttamispolitiikasta historian, nykypäivän ja tulevaisuuden näkökulmista. 
Kukka Hammarström: Suomalaisen monikulttuurisuuden mahdollisuudet

\section{ERILAISUUDESTA MONINAISUUTEEN}

Pasi Saukkosen kirjassa Erilaisuuksien Suomi. Vähemmistö- ja kotouttamispolitiikan vaihtoehdot on johdannon ja epilogin lisäksi kahdeksan lukua. Johdantoluvussa esitellään lyhyesti kirjan tavoitteet ja sisältö. Toisessa luvussa tarkastellaan Suomen valtion, yhteiskunnan ja kansakunnan historiallista rakentumista sekä sitä, miten kulttuurista ja poliittista erilaisuutta on aikojen kuluessa pyritty huomioimaan ja organisoimaan. Huomionarvoista on, että Suomessa on kyetty pitkälti rauhanomaiseen ongelmanratkaisuun ja tältä pohjalta myös onnistuttu edistämään yhteiskunnallista kehitystä. Luvuissa kolme ja neljä keskitytään kansainväliseen muuttoliikkeeseen ja sen vaiheisiin sekä integraatiopolitiikan kehitykseen niin Suomen kuin laajemmin Euroopan alueen näkökulmasta. Monien Euroopan maiden maahanmuutto- ja kotouttamispolitiikat eroavat toisistaan, vaikka niiden käsitykset valtiosta ovatkin pitkälti rakentuneet kansallisvaltioajattelulle.

Lukujen viisi ja kahdeksan aiheena ovat suomalaiset kielikysymykset ja kielipolitiikka. Viides luku valottaa kielen ja kansakunnan suhdetta menneestä nykypäivään. Kahdeksas luku puolestaan keskittyy erityisesti kielipolitiikkaan niin virallisten kansalliskielten suomen ja ruotsin kuin perinteisten vähemmistökielien ja muiden kieliryhmien osalta. Erityistä huomiota kiinnitetään tällä hetkellä ajankohtaiseen keskusteluun ruotsin kielen asemasta Suomessa. Luvussa esitetään myös konkreettisia ehdotuksia suomalaisen kielipoliittisen järjestelmän kehittämiseksi.

Kuudes, seitsemäs ja yhdeksäs luku lähestyvät monikulttuurisuutta erilaisista näkökulmista. Kuudennessa luvussa pohditaan monikulttuurisuuden ja multikulturalismin käsitteitä sekä niiden teoreettisten sisältöjen ja suomalaisen kotouttamis- ja vähemmistöpolitiikan kohtaamista käytännön tasolla. Seitsemäs luku tarkastelee suomalaisen yhteiskunnan etnistä ja kulttuurista rakennetta ja niitä koskevia tulevaisuuden kehityskulkuja. Viimeisessä eli yhdeksännessä luvussa käsitellään suomalaisen monikulttuurisuuden vaihtoehtoja. Aiheina ovat valtion ja kansankirkkojen suhde sekä muiden uskonnollisten yhteisöjen asema Suomessa sekä laajemmin monikulttuurisen yhteiskunnan yhteiset toimintasäännöt. Lopuksi tartutaan vielä syrjintään ja rasismiin sekä erilaisiin vaihtoehtoihin niiden ehkäisemiseksi.

\section{LIIKKUVA MAAILMA JA SUOMALAINEN MAAHANMUUTTO}

Muuttajat. Kansainvälinen muuttoliike ja suomalainen ybteiskunta -teoksen luvut sijoittuvat neljän aihealueen alle. Jokaisen luvun lopusta löytyy lyhyt kappale, josta löytyy lisätietoa kuhunkin aiheeseen liittyvästä kirjallisuudesta ja tutkimuksesta. Kirja sisältää myös runsaasti kuvioita, taulukoita ja tietolaatikoita. Kirjan ovat toimittaneet Tuomas Martikainen, Pasi Saukkonen ja Minna Säävälä. Kirjoittajina on yhteensä 24 eri tieteenalojen asiantuntijaa. Edustettuina ovat muun muassa sosiologia, taloustiede, oikeustiede, valtio-oppi, kulttuuripolitiikka, antropologia, uskontotiede, sosiaalipsykologia, maantiede, kielitiede ja viestinnäntutkimus. 
Johdantoluvussa Martikainen, Saukkonen ja Säävälä avaavat kirjan taustoja ja tavoitteita sekä esittelevät lyhyesti jokaisen kappaleen. Ensimmäisen aihealueen luvut käsittelevät kansainvälisen ja suomalaisen muuttoliikkeen historiaa, sen oikeudellista sääntelyä sekä lopuksi maahanmuutto- ja kotouttamispolitiikkaa erityisesti Suomen osalta. Toisen aihealueen luvut keskittyvät maahanmuuttoon perheilmiönä, maahanmuuttajien asumiseen ja alueelliseen sijoittumiseen Suomen näkökulmasta sekä hyvinvointivaltion haasteisiin maahanmuuttajien hyvinvoinnin kannalta.

Kolmannen aihealueen luvuissa tarkastellaan muuttoliikkeeseen liittyviä kielikysymyksiä ja kielitaidon käsitettä, koulutuksen merkitystä osana maahanmuuttajien sopeutumista, maahanmuuton ja työmarkkinoiden suhdetta sekä maahanmuuttajien työllistymistä ja asemaa työmarkkinoilla. Neljännen ja viimeisen aihealueen luvut käsittelevät etnisten ryhmien välisiä suhteita, akkulturaatiota sekä suomalaisen yhteiskunnan asenneilmapiiriä, maahanmuuttajien osallistumista politiikkaan ja yhdistystoimintaan sekä lopuksi maahanmuuton käsittelyä suomalaisessa mediassa.

\section{MuUtTuva monikultTuURinen SuOMi}

Kansainvälisellä muuttoliikkeellä on pitkät juuret ja myös suomalaiset ovat aikojen saatossa muuttaneet muihin maihin. Tänä päivänä yhteiskunnassa käytävässä keskustelussa tuntuu kuitenkin usein unohtuvan se seikka, että hekin edustavat omassa tilanteessaan maahanmuuttajia jossain muualla. Muuttajat-teoksen viimeisessä luvussa Karina Horsti huomauttaa, että esimerkiksi mediateksteissä muualle muuttaneita suomalaisia ei koskaan kutsuta maahanmuuttajiksi vaan siirtolaisiksi. Hän lisää myös, että julkisessa puheessa suomalainen ulkomaille kohdistuva siirtolaisuus ja maastamuutto eivät kohtaa nykyisin käytävää keskustelua vastaavasti Suomeen suuntautuvasta maahanmuutosta.

Maahanmuutto nykyisessä muodossaan on Suomessa vasta verrattain nuori ilmiö, joten pitkän aikavälin tutkimus- ja tilastotietoja ei vielä ole saatavilla. Vertailut kansainväliseen aineistoon, joka sisältää esimerkiksi laaja-alaisempaa tietoa maahanmuutosta useamman sukupolven ajalta, ovat siis paikallaan, kun pyritään hahmottamaan tulevaisuuden kannalta toimivia ratkaisuja. Muuttajat- ja Erilaisuuksien Suomi -teokset valottavat suomalaisen maahanmuutto- ja vähemmistöpolitiikan historiallisia ja yhteiskunnallisia taustoja ja nykytilaa sekä purkavat samalla monia maahanmuuttoon liittyviä uskomuksia. On myös tärkeää ymmärtää, että maahanmuuttajat eivät ole yhtenäistä, kasvotonta massaa, vaan jokaisen muuttajan taustalla vaikuttavat hänen aiemmat elämänvaiheensa ja myös maahanmuuton motiivit vaihtelevat paljon. Tämä kiteytyy hyvin Muuttajat-teoksen johdannossa:

\footnotetext{
Muuttoliikkeellä on suuria vaikutuksia sekä muuttajien lähtömaissa että tulomaissa. Muutto koskettaa muuttajien lisäksi suurta joukkoa perheenjäseniä ja muita läheisiä. Muuttajat vaikuttavat ympäröivään yhteiskuntaan omalla elämällään ja toiminnallaan sekä perheidensä, sosiaalisten kontaktiensa, työpaikkojensa ja ylirajaisten eli transnationaalien verkostojensa kautta. (s. 13)
} 
Molemmissa teoksissa pohditaan myös yleisellä tasolla suomalaista maahanmuutto-, kotouttamis- ja vähemmistöpolitiikkaa. Eräs niiden merkittävä yhteinen ongelma on, etteivät poliittinen ja hallinnollinen retoriikka välttämättä aina konkretisoidu käytännössä ja yhteiskunnallisessa toiminnassa. Tähän ovat syynä käytännön tasolla tapahtuvat arvovalinnat ja rajaukset, mutta ennen kaikkea puutteellinen resurssointi. Pasi Saukkonen peräänkuuluttaa omassa Erilaisuuksien Suomi -kirjassaan poliittista, pitkän aikavälin muutokseen valmistautumista nykyisen ja usein lyhytnäköisen, ajankohtaista tilannetta koskevan reagoinnin sijaan. Hän korostaa kuitenkin, että Suomen kohdalla on myös onnistuttu ja edistytty monissa asioissa ja tämä tulisi muistaa pelkkien ongelmien korostamisen sijaan.

Olettavaa on, että suomalaisen yhteiskunnan etninen ja kulttuurinen kirjo tulee jatkossakin lisääntymään. Maahan muuttanutta väestöä seuraavat sukupolvet tulevat edustamaan uudenlaista, monikulttuurisuudesta ammentavaa suomalaisuutta. Nyt tehtävät päätökset luovat pohjan sille, millaisena tämä tulevaisuus aikanaan tulee toteutumaan. Sopeutuminen uuteen elinympäristöön tapahtuu ennen kaikkea vuorovaikutteisesti. Miten se käytännössä toteutuu, riippuu paitsi muuttajan omista valmiuksista, myös vastaanottavan yhteiskunnan ja sen yksilöiden edellytyksistä. Onnistunut sopeutuminen edellyttää yhteistä käsitystä siitä, mitä eri osapuolilta odotetaan. Tässä myös valtiollisella päätöksenteolla ja erityisesti mahanmuutto-, kotoutumis- ja vähemmistöpolitiikalla on tärkeä roolinsa.

\section{LOPUKSI}

Teokset ovat profiililtaan hieman erilaisia. Erilaisuuksien Suomi on melko yleistajuinen ja lukijaystävällinen. Luettavuuteen vaikuttaa osaltaan myös viitteiden säästeliäs käyttö. Kirjan sisältö pohjautuu monilta osin kirjoittajan aiempiin julkaisuihin, joista löytyy myös tarkennettuja tietoja eri lukujen osalta kirjan lopusta. Valinta tekee tekstistä helpommin lähestyttävän myös tiedeyhteisön ulkopuoliselle lukijalle, ja kuten kirjassa todetaan, sen tarkoitus onkin ennen kaikkea herättää (kansalais)keskustelua aiheesta. Muuttajat-teoksen tarkoitus on puolestaan ollut ennen kaikkea kerätä yhteen eri tieteenalojen tuottamaa, aihepiiriä koskevaa tietoa, ja se on laaja-alainen yleisesitys. Paikoitellen hyvin runsaista tekstinsisäisistä viitteistä, lukuisista taulukoista ja kirjoittajien erilaisista kirjoitustyyleistä huolimatta kirjan luettavuus on yllättävän hyvä. Lukijan mielenkiinto pysyy vaivatta yllä, sillä luvut ovat tarpeeksi lyhyitä, tiiviitä ja aiheiltaan vaihtelevia.

Yhdessä luettuina teokset täydentävät toisiaan onnistuneesti. Häiritseviä päällekkäisyyksiä ei juuri löydy ja uskoakseni tämä onkin otettu huomioon jo kirjoja työstettäessä. Oma valintani lukea Saukkosen Erilaisuuksien Suomi ensin osoittautui oikeaksi, sillä kyseinen kirja keskittyy laajempaan yhteiskunnallis-historialliseen perspektiiviin ja taustoittaa näin osaltaan sopivasti myös Muuttajat-kirjassa käsiteltyjä asioita. Teosten anti on ehdottomasti kattavin ja monipuolisin kokonaisuutena ja yhdessä käytettyinä. Niiden sisältörakenteessa on kuitenkin otettu huomioon mahdollisuus keskittyä tiettyyn aihealueeseen, kuten esimerkiksi kielipolitiikkaa koskeviin kysymyksiin. Suosittelen 
Kukka Hammarström: Suomalaisen monikulttuurisuuden mahdollisuudet

lämpimästi molempia teoksia yhdessä ja erikseen kaikille suomalaisesta maahanmuutto-, vähemmistö- ja kotouttamispolitiikasta sekä monikulttuurisuudesta ja niitä koskevasta ajankohtaisesta keskustelusta kiinnostuneille.

Filosofian maisteri Kukka Hammarström on folkloristiikan jatko-opiskelija Helsingin yliopistossa. 